\title{
Quality Evaluation of Paneer Prepared with Sheep and Camel Milk with Spices Incorporation
}

\author{
Rohit Meena $^{1 *}$, Basant Bais ${ }^{1}$, Y. P. Gadekar ${ }^{1}$, Ashok Prajapat ${ }^{2}$, \\ Lokesh Tak ${ }^{2}$ and Devender Kumar ${ }^{2}$ \\ ${ }^{1}$ Department of Livestock Products Technology, CVAS, RAJUVAS, Bikaner-334001, India \\ ${ }^{2}$ ICAR-CSWRI, Avikanager, Tonk, India \\ *Corresponding author
}

\section{A B S T R A C T}

\section{Keywords}

Sheep milk, Camel milk, Texture analysis, Proximate, Probiotic

\section{Article Info}

\section{Accepted:}

18 August 2020

Available Online:

10 September 2020
In the present study, textural and composition parameters of paneer prepared with sheep and camel milk containing with different spices. Paneer is of great value in diet, especially in the Indian vegetarian context, because it contains a fairly high level of fat and proteins as well as some minerals, especially calcium and phosphorous. The high protein and overall solid contents of sheep milk make it particularly appropriate for cheese and yoghurt making. The biological and functional value of camel milk, make it more appropriate for human health. The results of the study indicated that the product has good acceptability and major benefits as human food. The values obtained for texture analysis of spices incorporated sheep and camel milk paneer were found to be appropriate for human consumption.

\section{Introduction}

Milk is highly nutritious and supplies body building proteins, bone forming minerals, healthful vitamins and provide energy giving lactose and milk fat. It provides essential nutrients and make a significant contribution to the required nutrient intakes for calcium, magnesium, selenium, riboflavin, vitamin $\mathrm{B}_{12}$ etc. it is very good source of high-quality, i.e. casein and whey proteins. Insoluble milk proteins are called casein, whereas soluble proteins are known as whey proteins. Both of these groups of milk proteins are considered to be of excellent quality, with a high proportion of essential amino acids and good digestibility. Casein forms the majority $(80 \%)$ of proteins in milk.

The physicochemical and nutritional characteristics of sheep milk make it suitable for the manufacture of products containing prebiotic ingredients and probiotic bacteria in the functional food market. Sheep milk contains one and half times more protein than cow milk (up to 6-7\%), and has more A, $\mathrm{B}_{1} \&$ $\mathrm{B}_{12}$ vitamins. Sheep milk is an important attribute of food of many nations in Europe 
Asia and the Middle East. Mostly the milk products such as yogurt, kefir, cheese, butter are made from sheep milk. It also has simple lipids (diacylglycerols, monoacylglycerols, and cholesterol esters), complex lipids (phospholipids), and liposoluble compounds (sterols, cholesterol esters, hydrocarbons). Sheep colostrum is also higher in basic nutrients than cow colostrum in the early postpartum period: fat $13.0 \%$ and $5.1 \%$, protein $11.8 \%$ and $7.1 \%$, lactose $3.3 \%$ and $3.6 \%$, minerals $0.9 \%$ and $0.9 \%$ total solids $28.9 \%$ and $15.6 \%$ respectively (Park et al. 2007).

Sheep milk proteins are also important sources of bioactive ACE inhibitory peptides and antihypertensive peptides. They can protect and control microbial infections against non-immune diseases. The total antibacterial effect in milk exceeds the sum of the individual contributions of immunoglobulin and non-immunoglobulin proteins such as lactoferrin, lactoperoxidase, lysozyme and other peptide proteins. In fermented milk products such as yogurt, sour milk and cheese, a variety of naturally formed bioactive peptides have been found. Bioactive peptide can be used as a potent drug with well-defined pharmacological effects in the formulation of nutraceuticals that improve health (Atanasova and Ivanova, 2010).

Camel milk is known for its medicinal properties, which are widely exploited for human health, as in several countries from the ex-Soviet Union (Kenzhebulat et al., 2000) and developing countries (Mal et al., 2006). Camel milk is considered to have anticancerous (Magjeed, 2005), hypo-allergic (Shabo et al., 2005) and anti-diabetic properties (Agarwal et al., 2003). A high content in unsaturated fatty acids contributes to its overall dietary quality (Karray et al., 2005; Konuspayeva et al., 2008). The low quantity of $\beta$-casein and the lack of $\beta$ - lactoglobulin are linked to the hypo-allergic effect of camel milk. The low quantity of $\beta$ casein and the lack of $\beta$-lactoglobulin are linked to the hypo-allergic effect of camel milk. Other components such as lactoferrin, immunoglobulin, lysozyme or vitamin $\mathrm{C}$ were reported to play a central role in the determination of these properties (Elagamy et al., 1996; Konuspayeva et al., 2007).

Paneer is of great value in diet, especially in the Indian vegetarian context, because it contains a fairly high level of fat and proteins as well as some minerals, especially calcium and phosphorous. Paneer is a rich source of fat soluble vitamins $\mathrm{A}, \mathrm{D}$ and animal protein available at a comparatively lower cost and forms an important source of animal protein for vegetarians. Over and above its high protein content and digestibility, the biological value of protein in paneer is in the range of 80 to 86 (Shrivastava and Goyal, 2007).

Superior nutritive value of paneer is attributed to the presence of whey proteins that are rich source of essential amino acids. Due to its high nutritive value, paneer is an ideal food for the expectant mothers, infants, growing children, adolescents and adults. Paneer is also recommended by the clinicians for diabetic and coronary heart disease patients (Chopra and Mamtani, 1995). Keeping in view to harness maximum health benefits of sheep and camel milk paneer, present study was undertaken to develop paneer from sheep and camel milk and evaluate its quality.

\section{Materials and Methods}

Proximate analysis of paneer was done according to method described by A.O.A.C. (2000). TAXTplus Texture Analyzer (Stable Micro System Ltd., Godalming, UK) use to perform a more comprehensive analysis of the paneer texture. 


\section{Product development}

Provide sources of milk for sheep and camel then how paneer was prepared products.

$\mathrm{T}_{0}$ - sheep and camel milk paneer without inclusion of any spices,

$\mathrm{T}_{1}$ - sheep and camel milk paneer with inclusion of black pepper $(0.6 \%)$,

$\mathrm{T}_{2}$ - sheep and camel milk paneer with inclusion of cinnamon $(0.6 \%)$,

$\mathrm{T}_{3}$ - sheep and camel milk paneer with inclusion of black pepper + cinnamon $(0.3 \%$ $+0.3 \%)$.

Moisture content of sheep and camel milk paneer was $(55.51 \pm 0.12 \%), \mathrm{T}_{1}, \mathrm{~T}_{2}$, and $\mathrm{T}_{3}$ $(55.27 \pm 0.04 \%, 55.40 \pm 0.07 \%$ and $55.40 \pm$ $0.17 \%$ ) respectively. The crude protein content of control, $\mathrm{T}_{1}, \mathrm{~T}_{2}$ and $\mathrm{T}_{3}$ were $17.19 \pm$ $0.15 \%, 17.50 \pm 0.08 \%, 17.28 \pm 0.05 \%$ and $17.34 \pm 0.11 \%$ respectively. The mean ether extract percentage of sample $\mathrm{T}_{0}, \mathrm{~T}_{1}, \mathrm{~T}_{2}$ and $\mathrm{T}_{3}$ were $24.3 \pm 0.11 \%, 24.10 \pm 0.06 \%, 24.22 \pm$ $0.08 \%$ and $24.31 \pm 0.09 \%$ respectively. The mean carbohydrate percentage of sample $\mathrm{T}_{0}$, $\mathrm{T}_{1} \mathrm{~T}_{2}$ and $\mathrm{T}_{3}$ were found $2.15 \pm 0.11 \%, 2.34 \pm$ $0.09 \%, 2.29 \pm 0.061 \%$ and $2.39 \pm 0.12 \%$ respectively. The total ash percentage of sample $\mathrm{T}_{0}, \mathrm{~T}_{1} \mathrm{~T}_{2}$ and $\mathrm{T}_{3}$ were found $0.88 \pm$ $0.07 \%, 0.82 \pm 0.05 \%, 0.76 \pm 0.072 \%$ and 0.88 $\pm 0.10 \%$ respectively whereas the value of $0 \pm$ $0 \%, 0.05 \pm 0.002 \%, 0.09 \pm 0.002 \%$ and $0.67 \pm$ $0.001 \%$ were observed for the mean crude fibre percentage of sample $T_{0}, T_{1}, T_{2}$ and $T_{3}$ respectively (Table 1).

\section{Textural properties of spices incorporated sheep and camel milk paneer}

The textural properties of spices incorporated sheep and camel milk paneer has been presented in Table 2.

\section{Hardness}

Hardness is the most commonly evaluated feature for the analysis of texture. It may be described as the force needed to achieve a deformation. During textural determination the hardness is the peak force of the first compression of the product.

The mean \pm SE hardness values obtained for the spices incorporated sheep and camel milk paneer were in the range of $1656.53 \pm 37.47$ to $2055.45 \pm 13.57 \mathrm{~g}$. The value of sheep and camel milk paneer without incorporation of any spices $\left(T_{0}\right)$ was $1656.53 \pm 37.47$. The values of black pepper incorporated sheep and camel milk paneer $\left(T_{1}\right)$ was $1845.5 \pm 36.32$.

Whereas the value of cinnamon incorporated sheep and camel milk paneer $\left(\mathrm{T}_{2}\right)$ and black pepper + cinnamon incorporated sheep and camel milk paneer $\left(T_{3}\right)$ were $1915.03 \pm 17.30$ and $2055.45 \pm 13.57$ respectively.

The values obtained for hardness of spices incorporated sheep and camel milk paneer were found to be comparable with the findings of Mhatre (2007). The hardness values obtained by Mhatre (2007) for the paneer coagulated at various temperatures were in the range of 47.7 to $1649.7 \mathrm{gm}$. When the proportions of the soymilk, increases from 0 to $25 \%$, in the paneer sample hardness values decreases from 1251.8 to $160.4 \mathrm{gm}$, 1586.0 to $173.0 \mathrm{gm}, 1649.7$ to $184.0 \mathrm{gm}$ and 1177.2 to $152.1 \mathrm{gm}$ for coagulations temperatures of $80,85,90$ and $95^{\circ} \mathrm{C}$ respectively.

\section{Adhesiveness}

The negative forces area for the first bite, representing the work necessary to pull compressing probe away from sample is defined as adhesiveness. 
Table.1 Proximate analysis (Mean \pm SE) of spices incorporated sheep and camel milk paneer

\begin{tabular}{|l|c|c|c|c|}
\hline \multicolumn{1}{|c|}{ Constituent (\%) } & $\mathbf{T}_{\mathbf{0}}$ & $\mathbf{T}_{\mathbf{1}}$ & $\mathbf{T}_{\mathbf{2}}$ & $\mathbf{T}_{\mathbf{3}}$ \\
\hline Moisture & $55.51 \pm 0.12$ & $55.27 \pm 0.04$ & $55.40 \pm 0.07$ & $55.4 \pm 0.17$ \\
\hline Crude Fibre & - & $0.05 \pm 0.002$ & $0.09 \pm 0.002$ & $0.67 \pm 0.001$ \\
\hline Crude Protein & $17.19 \pm 0.15$ & $17.50 \pm 0.08$ & $17.28 \pm 0.05$ & $17.34 \pm 0.11$ \\
\hline Ether Extract & $24.3 \pm 0.11$ & $24.10 \pm 0.06$ & $24.22 \pm 0.08$ & $24.31 \pm 0.09$ \\
\hline Carbohydrate & $2.15 \pm 0.11$ & $2.34 \pm 0.09$ & $2.29 \pm 0.061$ & $2.39 \pm 0.12$ \\
\hline Total ash & $0.88 \pm 0.07$ & $0.82 \pm 0.05$ & $0.76 \pm 0.072$ & $0.88 \pm 0.10$ \\
\hline
\end{tabular}

$\mathrm{T}_{0}$-sheep and camel milk paneer without any spices, $\mathrm{T}_{1}$ - sheep and camel milk paneer with black pepper $(0.6 \%), \mathrm{T}_{2}-$ sheep and camel milk paneer with cinnamon $(0.6 \%), \mathrm{T}_{3}$ - sheep and camel milk paneer with black pepper + cinnamon $(0.3 \%+0.3 \%)$

Table. 2 Texture analysis spices incorporated sheep and camel milk paneer (mean \pm SE)

\begin{tabular}{|c|c|c|c|c|}
\hline Parameter & $\mathbf{T}_{\mathbf{0}}$ & $\mathbf{T}_{\mathbf{1}}$ & $\mathbf{T}_{\mathbf{2}}$ & $\mathbf{T}_{\mathbf{3}}$ \\
\hline Hardness(gm) & $1656.53 \pm 37.47$ & $1845.5 \pm 36.32$ & $1915.03 \pm 17.30$ & $2055.45 \pm 13.57$ \\
\hline $\begin{array}{c}\text { Adhesiveness } \\
\text { (gm/sec) }\end{array}$ & $-26.61 \pm 0.44$ & $-24.45 \pm 0.30$ & $-30.85 \pm 0.57$ & $-21.2 \pm 0.49$ \\
\hline $\begin{array}{c}\text { Springiness } \\
\text { (mm) }\end{array}$ & $0.58 \pm 0.01$ & $0.31 \pm 0.04$ & $0.31 \pm 0.034$ & $0.23 \pm 0.07$ \\
\hline $\begin{array}{c}\text { Cohesiveness } \\
\text { (Mj) }\end{array}$ & $0.92 \pm 0.01$ & $0.63 \pm 0.02$ & $0.82 \pm 0.006$ & $0.62 \pm 0.01$ \\
\hline
\end{tabular}

$\mathrm{T}_{0}$-sheep and camel milk paneer without any spices, $\mathrm{T}_{1}-$ sheep and camel milk paneer with black pepper $(0.6 \%), \mathrm{T}_{2}-$ sheep and camel milk paneer with cinnamon $(0.6 \%), \mathrm{T}_{3}$ - sheep and camel milk paneer with black pepper + cinnamon $(0.3 \%+0.3 \%)$

The adhesiveness values obtained for the spices incorporated sheep and camel milk paneer were in the range from $-21.2 \pm 0.49$ to $-30.85 \pm 0.57 \mathrm{~g}$. The maximum value of adhesiveness was found for black pepper + cinnamon incorporated sheep and camel milk paneer $\left(\mathrm{T}_{3}\right)-21.20 \pm 0.49 \mathrm{~g}$. The value of sheep and camel milk paneer without incorporation of any spices $\left(\mathrm{T}_{0}\right)$ was $-26.61 \pm$ 0.44 . Whereas the value of black pepper incorporated sheep and camel milk paneer $\left(\mathrm{T}_{1}\right)$ and cinnamon incorporated sheep and camel milk paneer $\left(\mathrm{T}_{2}\right)$ were $-24.45 \pm 0.30$ and $-30.85 \pm 0.57$ respectively.

\section{Springiness}

Springiness means is how well a product springs back physically after it was deformed during the first compression and was allowed to wait for the target time between strokes.
The spring back is measured by the second compression down-stroke.

The springiness values obtained for the spices incorporated sheep and camel milk paneer were ranged from $0.23 \pm 0.07$ to $0.58 \pm 0.01$. The value of sheep and camel milk paneer without incorporation of any spices $\left(\mathrm{T}_{0}\right)$ was $0.58 \pm 0.01$. The value of black pepper incorporated sheep and camel milk paneer $\left(\mathrm{T}_{1}\right)$ was $0.31 \pm 0.04$. Whereas the value of cinnamon incorporated sheep and camel milk paneer $\left(\mathrm{T}_{2}\right)$ and black pepper + cinnamon incorporated sheep and camel milk paneer $\left(\mathrm{T}_{3}\right)$ were $0.31 \pm 0.034$ and $0.23 \pm 0.07$ respectively.

\section{Cohesiveness}

Cohesiveness is the ratio of first and second bite areas. It is defined as the extent to which 
a material can be deformed before its rupture and depends primarily on internal bond strength.

The maximum cohesiveness value was found in control $\left(\mathrm{T}_{0}\right)$ sheep and camel milk paneer $(0.92 \pm 0.01)$. The minimum value was black pepper + cinnamon $\left(\mathrm{T}_{3}\right)$ incorporated sheep and camel milk paneer $(0.62 \pm 0.01)$. The value of black pepper incorporated sheep and camel milk paneer $\left(\mathrm{T}_{1}\right)$ was $0.63 \pm 0.02$ and the value of cinnamn incorporated sheep and camel milk paneer $\left(T_{2}\right) 0.82 \pm 0.006$. The nature of the protein matrix and extent of fat dispersion may contribute to cohesiveness or tendency to adhere to it. Data related to cohesiveness of spices incorporated sheep and camel milk paneer is in line with result demonstrated by Shrivastav and Kumbhar (2010).

Thus from the present study it may be concluded that by the result of textural properties of sheep and camel milk paneer it may concluded that although the control paneer was best but among the spices incorporated paneer the $\mathrm{T}_{1}$ Is better as compared to $\mathrm{T}_{2}$ and $\mathrm{T}_{3}$.

\section{References}

A.O.A.C. (2000). Official methods of analysis, 17th edition, Association of Official Analytical Chemists, Washington, D.C.

Agarwal, R.P., Swami, S.C., Beniwal, R., Kochar, D.K., Sahani, M.S., Tuteja, F.C. and Ghouri, S.K. (2003). Effect of camel milk on glycemic control, risk factors and diabetes quality of life in type-1 diabetes: A randomized prospective controlled study. Journal of Camel Practice and Research, 10(1), 45-50.

Atanasova, J. and Ivanova, I. (2010). Antibacterial peptides from goat and sheep milk proteins. Biotechnology \& Biotechnological Equipment, 24(2), 1799-1803.

Chopra, S. and Mamtani, R. (1995). Say cheese or paneer? Indian Dairyman, 47: 27-29

Elagamy, E.I., Ruppanner, R., Ismail, A., Champagne, C.P., and Assaf, R. (1996). Purification and characterization of lactoferrin, lactoperoxidase, lysozyme and immunoglobulins from camel's milk. International Dairy Journal, 6(2), 129-145.

Karray, N., Lopez, C., Ollivon, M., and Attia, H. (2005). La matière grasse du lait de dromadaire: composition, microstructure et polymorphisme. Une revue. Oléagineux, Corps gras, Lipides, 12(5-6), 439-446.

Kenzhebulat, S., Ermuhan, B., and Tleuov, A. (2000). Composition of camel milk and its use in the treatment of infectious diseases in human. In Proceedings of the 2nd Camelid conference on Agroeconomics of Camelid Farming (p. 101).

Konuspayeva, G., Lemarie, É., Faye, B., Loiseau, G., and Montet, D. (2008). Fatty acid and cholesterol composition of camel's (Camelus bactrianus, Camelus dromedarius and hybrids) milk in Kazakhstan. Dairy Science and Technology, 88(3), 327-340.

Magjeed, N.A. (2005). Corrective effect of milk camel on some cancer biomarkers in blood of rats intoxicated with aflatoxin B1. Journal of the Saudi Chemical society, 9, 253-263.

Mal, G., Sena, D.S., Jain, V.K., and Sahani, M.S. (2006). Therapeutic value of camel milk as a nutritional supplement for multiple drug resistant (MDR) tuberculosis patients. Israel Journal of Veterinary Medicine, 61(3/4), 88.

Mhatre S.S. (2007). Studies on textural properties of paneer made from soymilk 
blended with different levels of dairy milk. M.Tech Thesis presented to college of technology and engineering Maharana Pratap University of agriculture and technology, Udaipur.

Park, Y.W., Juárez, M., Ramos, M., and Haenlein, G.F.W. (2007). Physicochemical characteristics of goat and sheep milk. Small ruminant research, 68(1-2), 88-113.

Shabo, Y., Barzel, R., Margoulis, M., and Yagil, R. (2005). Camel milk for food allergies in children. Imaj-ramat gan7(12), 796.

Shrivastav, S. and Kumbhar, B. K. (2010). Textural profile analysis of paneer dried with low pressure superheated steam. Journal of food science and technology, 47(3), 355-357.

Shrivastava, S. and Goyal, G.K. (2007). Preparation of paneer- A Review. Indian J. Dairy Sci., 60(6), 377-388

\section{How to cite this article:}

Rohit Meena, Basant Bais, Y. P. Gadekar, Ashok Prajapat, Lokesh Tak and Devender kumar. 2020. Quality Evaluation of Paneer Prepared with Sheep and Camel Milk with Spices Incorporation. Int.J.Curr.Microbiol.App.Sci. 9(09): 2458-2463.

doi: https://doi.org/10.20546/ijcmas.2020.909.306 